\title{
Striga Infestation in Kenya: Status, Distribution and Management Options
}

\author{
Evans Atuti Atera ${ }^{1,2}$, Takashige Ishii ${ }^{2}$, John Collins Onyango ${ }^{3}$, Kazuyuki Itoh $^{2} \&$ Tetsushi Azuma $^{2}$ \\ ${ }^{1}$ Department of Technical Services, Lake Basin Development Authority, Kisumu, Kenya \\ ${ }^{2}$ Graduate School of Agricultural Science, Kobe University, Kobe, Japan \\ ${ }^{3}$ Department of Horticulture and Botany, Maseno University, Kisumu, Kenya \\ Correspondence: Evans Atuti Atera, Department of Technical Services, Lake Basin Development Authority \\ P.O.Box 1516-40100, Kisumu, Kenya. Tel: 254-572-027-227. E-mail: eatera@yahoo.com
}

Received: August 13, 2012 Accepted: September 28, 2012 Online Published: January 10, 2013

doi: 10.5539/sar.v2n2p99 URL: http://dx.doi.org/10.5539/sar.v2n2p99

\begin{abstract}
Striga spp. is considered to be the greatest biological constraint to food production in sub-Saharan Africa, a more serious problem than insects, birds and plant diseases. They are among the most specialized root-parasitic plants inflicting serious injury to their host depriving them water, minerals and photosynthate. The greatest diversity of Striga spp. occurs in grassland. However, Striga hermonthica mainly occurs in farmland infecting grasses. The parasite devastating effect is accomplished prior to its emergence from the soil. It may cause yield losses in cereals ranging from $15 \%$ under favourable conditions to $100 \%$ where several stress factors are involved, thereby affecting the livelihood of millions of resource-poor farmers. Piecemeal approach to address one aspect of Striga problem at a time has been a setback in technology transfer to producers. Future Striga control programs should not be conducted separately, but should rather be conducted in an integrated approach that combines research talents of various institutions. This will facilitate collaborative research and achieve qualitative interaction between stakeholders, which can easily produce reliable technologies that are practical and available to farmers. Striga being a pervasive pest, time is of essence in controlling it. There is an urgent need for the establishment of policies to promote, implement, and ensure a long-term sustainable Striga control program.
\end{abstract}

Keywords: control options, genetic diversity, occurrence, S. hermonthica, Kenya

\section{Introduction}

Striga, commonly known as witchweed, is the most economically important parasitic weed seed plant in the world. It is a genus of 28 species of parasitic plants that occur naturally in parts of Africa, Asia and Australia. The genus is now classified in the family of Orobanchaceae although earlier authors placed it in Scrophulariaceae (Gethi et al., 2005). Even though most Striga spp. do not affect agricultural production, some have devastating effects on crops particularly those planted by subsistence farmers (Mohamed et al., 2001; Westerman et al., 2007). The major agricultural Striga species are Striga hermonthica (Del.) Benth and S. asiatica (L.) Kuntze infecting cereals (maize, sorghum, millet and upland rice), and S. gesneriodes (willd.) Vatke legumes (cowpea) and tobacco. Other species such as $S$. forbesii (Benth.) and $S$. aspera (Willd.) Benth have been reported to have sporadic effects on cereal crops in their limited locations (Parker, 2009). Crops such as wheat (Ejeta, 2007) and napier grass (Atera \& Itoh, unpublished data, 2012) previously unaffected by Striga are now showing serious infestation in Sahel.

Striga hermonthica problem has been in existence as early as 1936 in the fields of farmers within Lake Victoria Basin, western Kenya (Watt, 1936; Khan et al., 2006). During the last 20-30 years, it has attained devastating proportions due to cereal mono-cropping (Oswald, 2005). The parasite is reported to be infecting about 217,000 ha in Kenya, causing annual crop loss of US \$53 million (Woomer \& Savala, 2009). These losses largely depend on Striga density, host species and genotype, land use system, soil nutritional status and rainfall patterns (Atera et al., 2012a). The most affected are the poor subsistence farmers, who are not aware of the threat that Striga poses to their land quality and food security as the weed continues to increase its soil seed bank and spreading to new areas. 
A survey conducted in the Sudan savannah zone of Ghana showed that an average number of 9,384 seeds $\mathrm{m}^{-2}$ was found in the Land that had been returned to cultivation after fallow. However, some fields had seeds in excess of 14,900 seeds $\mathrm{m}^{-2}$ (Abunyewa \& Padi, 2003). Van Delft et al. (1997) reported that a single Striga plant can produce up 4,827 seeds, excluding an approximate similar amount of seeds present in maturing capsules in western Kenya. They estimated the average number of seeds produced per mature Striga seed capsule to be 1,188. According to Woomer and Savala (2009), Striga has infected farmer's fields in western Kenya with an average of 161 million seeds per ha resulting in three parasitic stems per maize plant. Other studies in the region showed that Striga density was at least 14 plants per $\mathrm{m}^{2}$ (MacOpiyo et al., 2010). These results imply that only a few Striga plants are required to make cereal production unsustainable in this region.

The purpose of this paper, therefore, is to examine the incidence of Striga hermonthica in Kenya and research achievements on its control. Some of the concepts in this paper will be drawn from our research of seven years in Striga infestation and occurrence, and cereal production in western Kenya. Agricultural production and costraints that limit its productivity will be assessed. A review on genetic diversity of $S$. hermonthica and its related species will be highlighted. Finally, the achievements of research on Striga control options available for farmers and their potential applicability will be discussed.

\section{Agriculture and Distribution of Striga in Kenya}

\subsection{Land Use}

The agricultural sector in sub-Saharan Africa is the key source of food, incomes, employment, and more often, foreign exchange. In Kenya, agriculture is an important economic activity and accounts for approximately $26 \%$ of GDP (Gok, 2010). It is a major contributor to foreign exchange earnings; even though less than $8 \%$ of the land is used for crop production. The land suitable for cultivation is about $20 \%$, of which only $12 \%$ receive adequate rainfall for agricultural production and about $8 \%$ is regarded as medium potential land. The rest of the land is arid and semiarid. Farming in Kenya is carried out by small scale holders with limited technology who own not more than two hectares. These small farm production, operated by about three million farming families, account for $75 \%$ of total production in Kenya (Gitau et al., 2009). It is estimated that about $80 \%$ of the workforce in the country is engaged in agriculture/food processing.

\subsection{Crop Production}

The major food crops grown in Kenya are maize, sorghum, sweet potatoes, wheat, rice, beans, finger millet and cassava (Taylor, 2009; Atera et al., 2012b). According to FAO (2006), cereal yield in SSA increased by only $29 \%$ between 1961 and 2005 compared to 177\% in Asia and 144\% in Latin America. On the other hand however, in the same period the population grew by $216 \%$ in the SSA (United Nations Population Division, 2007). The implication of this statistics is that production of cereals in SSA has to be increased to feed the growing population. In Kenya, cereal consumption was approximately 3.9 million tonnes (Ministry of Agriculture, 2010) while the production was 2.9 million tonnes in 2009 (Table 1). A preliminary forecast by FAO showed that Kenya needs to import 2.3 million tonnes of cereals to bridge a production deficit over 2011/12 cropping season. Cereals play a central role for food supply but its production has lagged behind. The production capacity of the country's food systems has not kept pace with the surging demand for food. The low yield recorded in the country is due to constraints of nutrient depletion, loss of organic matter and drought. Production of cereals is also negatively influenced by incidence of pests and diseases such as bird damage, leaf blight and the parasitic weed Striga.

\subsection{Food Security}

Food security situation in Kenya has deteriorated significantly under the umbrella of business-as-usual scenario which calls for anything short of a revolution. The food shortage trends have to be reversed by all means through appropriate agricultural technologies including replenishing soil fertility, use of certified seeds, utilizing Good Agricultural Practices (GAPs), reducing weed soil seed banks, disease and pest pressures (Bruce, 2010). Emphasis should not only be laid on technology transfer, but also on policies that will achieve sustainable productive growth and reduce food insecurity. It is absolutely essential that any interventions to increase crop production must be focused on the farmers. In addition, farmers should be empowered to participate as equal partners in development of new technologies that will fit into their farming systems. Striga weed undermines the struggle to attain food security, and so its control must be addressed by all means.

In Kenya, food security means maize (Zea mays L.) production. It is regarded as a source of food in the entire nation and produced by almost every farmer. In addition, some farmers consider it as a source of income. Maize is life to some communities in Kenya because of its famous use to prepare the stable dish "ugali". Unfortunately, 
the area which is considered to be the grain basket of the country is heavily infested by Striga (Figure 1), reducing yields of farmers' dependence by $30-100 \%$ (Bruce, 2010).

Table 1. Cereal production and consumption in Kenya in 2009

\begin{tabular}{llll}
\hline Crop & Area under crop cover (ha) & Production (tons) & Consumption (tons) \\
\hline Maize & $1,885,071$ & $2,442,823$ & $3,240,000$ \\
Wheat & 131,594 & 219,301 & 96,480 \\
Rice & 21,829 & 42,202 & 410,000 \\
Sorghum & 173,172 & 94,555 & 81,000 \\
Finger millet & 104,576 & 56,417 & 40,000 \\
\hline
\end{tabular}

Source: Ministry of Agriculture, Kenya, 2010.

\subsection{Origin and Occurrence of Striga}

It is believed that Striga hermonthica and S. asiatica originated in the Nubian hills of Sudan and Semien mountains of Ethiopia. These areas are also known to be the origin of sorghum and pearl millet which are readily infected by the witchweed (Ejeta, 2007). S. gesnerioides may have originated in West Africa. Over the years, Striga has spread to other parts of sub-Saharan Africa through the activities of man.

There are nine (9) Striga species found in Kenya (Table 2). Among them, S. hermonthica is considered to be the most dangerous and common particularly in the densely populated regions of Nyanza and Western Provinces of Kenya (Figure 2) (Dogget, 1965; MacOpiyo et al., 2010). S. asiatica is predominantly found in the coastal region infecting upland rice (Gethi et al., 2005) and exists sporadically in Isiolo, Busia and Naivasha (Mohamed et al., 2001). The species that is adapted as a pest of legume crops, $S$. gesneriodes, has a wide geographical distribution in Kenya compared to the other species. It occurs as far as Kilifi (Coastal province of Kenya) spreading to Homa hills (Nyanza province, western Kenya) infecting cow pea.

\subsection{Economic Importance of Striga}

Striga infestation causes a loss of $30-50 \%$ to Africa's agricultural economy on $40 \%$ of its arable land (Amudavi et al., 2007; Hearne, 2009). A survey conducted in 30 communities in Borno state, northern Nigeria, indicated that farmers' rated Striga infestation as the leading priority constraint together with low soil fertility to crop production (Dugje et al., 2006). Similar surveys (Weber et al., 1995; Kim et al., 1997) showed S. hermonthica as a serious problem in Guinea savanna of Nigeria and yield losses ranged from 10 to $100 \%$. In western Kenya, a survey of 83 farms revealed that $73 \%$ of the farms are infected with $S$. hermonthica (Woomer \& Savala, 2009). The average yield loss due to Striga is $1.15,1.10$ and 0.99 tons per hectare for maize, sorghum and millet, respectively (MacOpiyo et al., 2010). However, the damage can reach as high as 2.8 tons per ha in maize and sorghum in some locations with high Striga densities (Andersson \& Halvarsson, 2011). The loss represents $12.3 \%$ of the 2.4 million metric tonnes of maize that Kenya produces annually. This translates to about $39.6 \mathrm{~kg}$ of maize loss per capita, amounting to about $20 \%$ of a typical person's annual food requirement. Clearly, this shows the consequences of Striga infections are severe rendering small scale farmers helpless and often bewildered. It requires innovative and focused actions to assist them to reclaim health of their soil to overcome this agricultural scourge. 
A

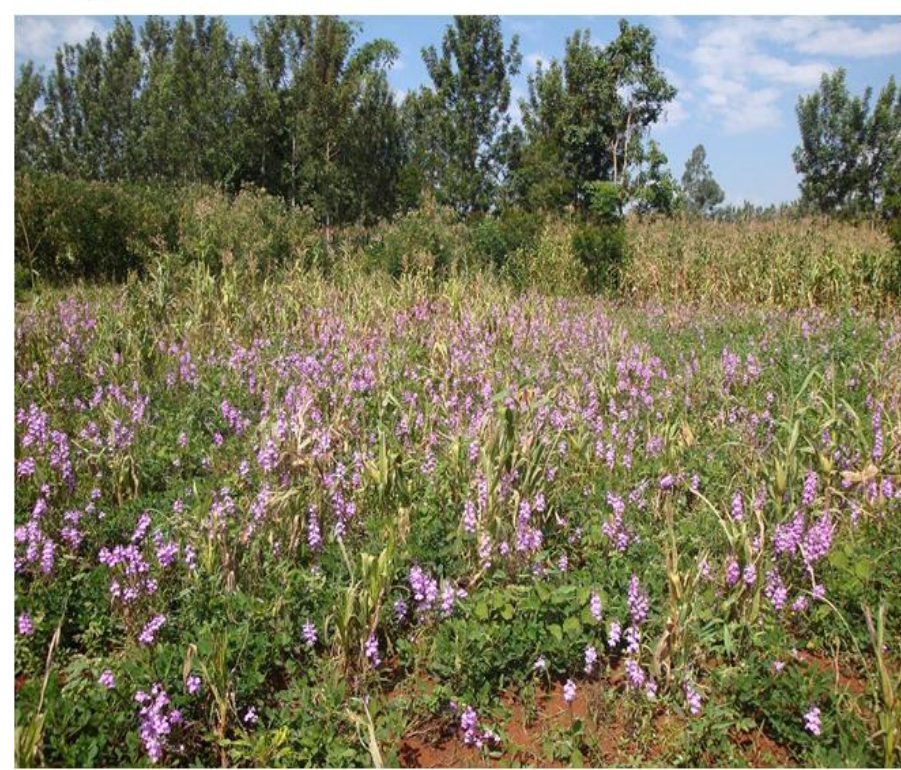

B

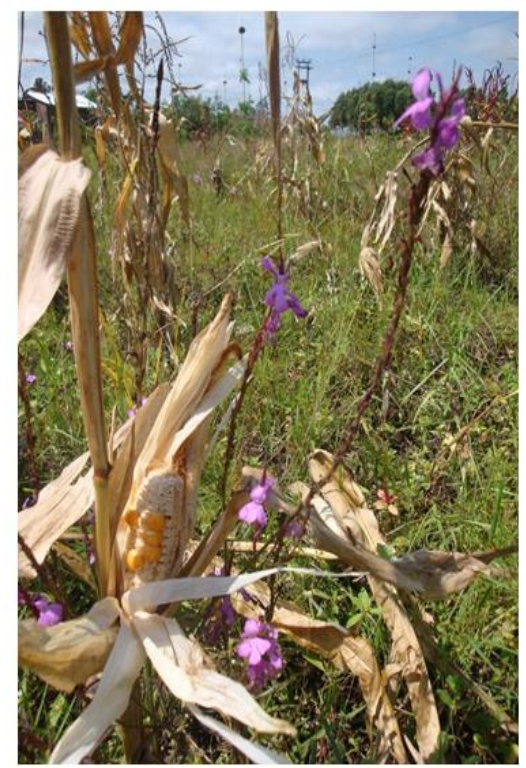

Figure 1. S. hermonthica infection in Busia, western Kenya: (A) Maize-groundnut intercrop with heavy infestation; (B) Reduction of yield in maize under Striga infestation

Table 2. Striga spp. distribution and occurrence in Kenya

\begin{tabular}{|c|c|c|}
\hline Striga species & Host plants & Occurrence area \\
\hline S. asiatica & $\begin{array}{l}\text { Maize, rice, sorghum, pearl millet, } \\
\text { finger millet, sugar cane, wild grasses }\end{array}$ & $\begin{array}{l}\text { Kilifi, Isiolo, Mathews range, Alupe, Daka Chom, } \\
\text { Kiunga }\end{array}$ \\
\hline S. bilabiata & Wild grasses & $\begin{array}{l}\text { Naivasha, Chyulu hills, Rumbia, Kahawa, } \\
\text { Mathews range }\end{array}$ \\
\hline S. elegans & Wild grasses & Nairobi, Loitokitok, Laikiapia, Rumuruti \\
\hline S. forbesii & Sorghum, rice, maize, sugar cane & $\begin{array}{l}\text { Narok, Mara plains, Kipini, Chyulu hills, Uasin } \\
\text { Gishu plateau, Trans Nzoia }\end{array}$ \\
\hline S.gesnerioides & Cow pea & $\begin{array}{l}\text { Kilifi, Buna, Homa hills, Rongo, Nairobi, } \\
\text { Naivasha }\end{array}$ \\
\hline S. hermonthica & $\begin{array}{l}\text { Maize, rice, sorghum, pearl millet, } \\
\text { finger millet, sugar cane, wild grasses }\end{array}$ & $\begin{array}{l}\text { Alupe, Churaimbo, Miwani, Bungoma, Kendu, } \\
\text { Migori, Kuria, Nyamira, Siaya, Homabay }\end{array}$ \\
\hline S. latericea & Sugar cane, wild grasses & $\begin{array}{l}\text { Samburu, Mariakani, Kwale, Voi, Machakos, } \\
\text { Sultan Hamud, Kilifi, Mwea }\end{array}$ \\
\hline S. lutea & Wild grasses & Kwale, Shimba hills, Embu, Chyulu hills \\
\hline S. pubiflora & Sugar cane, wild grasses & Kwale, Shimba hills, Voi \\
\hline
\end{tabular}

Source: Mohamed et al., 2001; Gethi et al., 2005; Khan et al., 2007; De Groote et al., 2008; Authors' own observations.

\section{Genetic Diversity of Striga strains}

The relatedness of species is commonly assessed by morphological characters. However, reliable closeness of parental species has been evaluated according to the level of successful hybridization and fertility of the resultant progeny (Murray et al., 1993). Based on their morphological similarities, it has been suggested that Striga species have formed complex groups (Aigbokhan et al., 2000). Some of these species such as S. hermonthica and $S$. aspera are found in the same locality, parasitizing the same cereal crops and wild grasses, sharing insect pollinators and can be intercrossed to produce seeds. Mohamed et al. (2007) proposed that there are several 
factors that have contributed to genetic diversity in Striga: (a) persistent seed bank of several generations of populations; (b) hybridization; (c) broad geographic distribution; (d) long distance dispersal and (e) locally adapted host races. Among these factors geographical distribution appears to play the greatest role in determining genetic differences in the species (Aigbokhan et al., 2000).

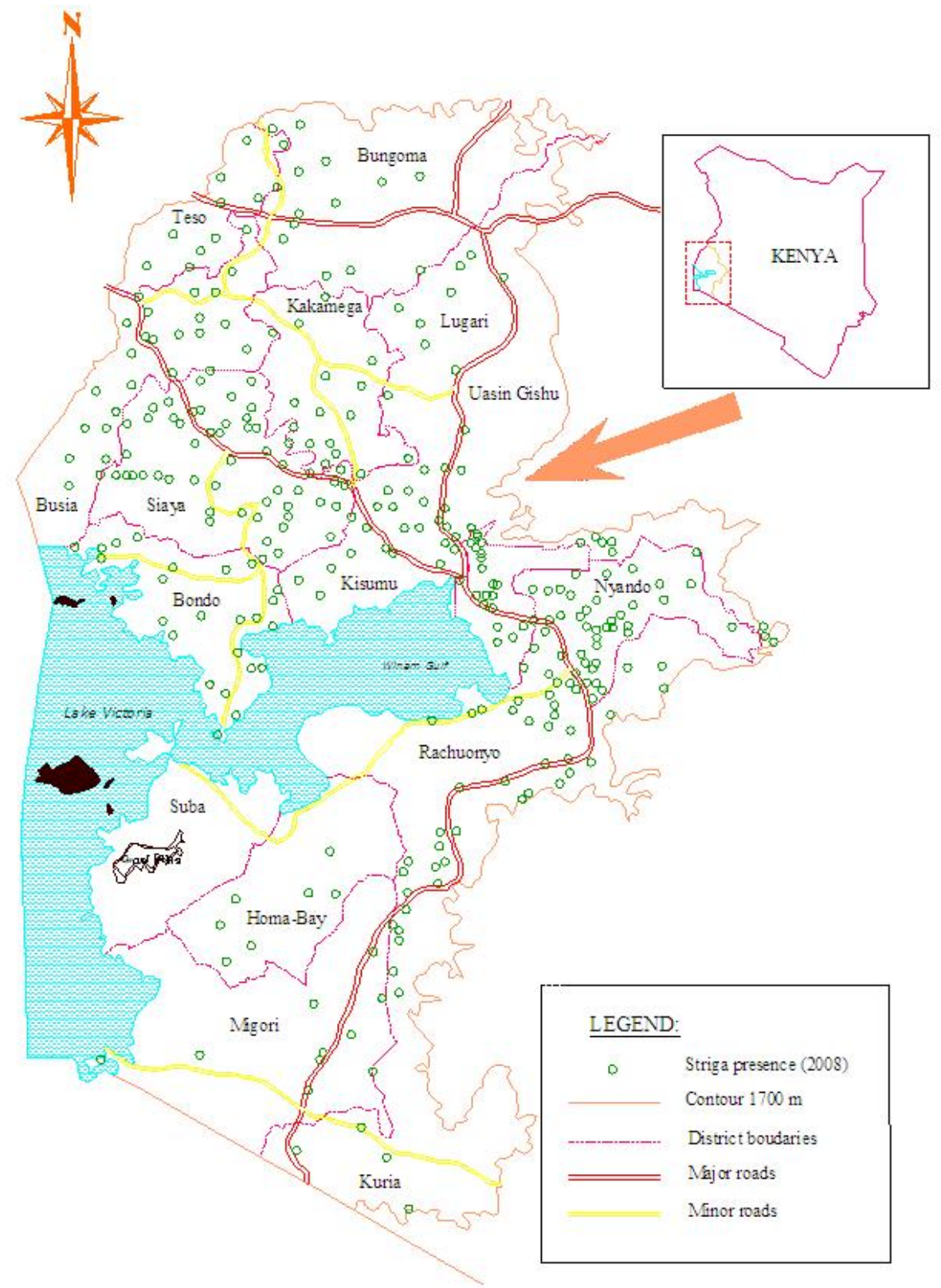

Figure 2. Part of western Kenya map showing Striga hermonthica infections (De Groote et al., 2008; Authors' own observations)

Considering the wide range of distribution of Striga spp., limited studies on genetic diversity have been conducted in Kenya (Gethi et al., 2005). However, recent molecular advancements have provided the necessary tools that can be used in Striga diversity studies. These include polymerase chain reaction (PCR) and randomly amplified polymorphic (RAPD) which offer better characterization due to their high level of polymorphism compared to other markers such as morphological markers. Studies conducted on genetic diversity on $S$. hermonthica from Mali, Kenya and Nigeria showed high levels of variation existing between and within populations (Koyama, 2000). However, Gethi et al. (2005) reported that there is $90 \%$ similarity in $S$. hermonthica population collected from Kenya. He has argued that there seems to be substantial gene flow between Striga populations leading to low differentiation and seed dispersal has been basically through 
contaminated seeds.

However, using $\mathrm{F}_{\mathrm{ST}}$ standards value range (Wright, 1978) of 0.15 to 0.25 for highly differentiated population and 0.05 to 0.15 for moderately differentiated, Welsh and Mohamed (2011) showed that $S$. hermonthica samples collected from Ethiopia were genetically different and all populations were significantly different from each other. Nevertheless, he attributed Kenyan population similarity to a small area sampled covering only $0.5^{\circ}$ latitude and less than $0.1^{\circ}$ longitude. Other studies of $S$. hermonthica populations infesting cereal crops from several countries in western, eastern and central Africa using isozyme markers showed little genetic diversity to genetic diversity levels of up to 6.8\% (Bharathalakshmi et al., 1990; Olivier et al., 1998).

More detailed analysis of genetic diversity in S. hermonthica population is required for understanding the parasite well for effective management. The parasite is said to have the ability to withstand a wide range of climatic conditions as well as to quickly adapting to different hosts and environments (Welsh \& Mohamed, 2011). This makes it even more difficult to develop universally resistant host crops, and effort towards obtaining resistant cultivars may need to take the view that Striga species are diverse.

\section{Research Achievements}

Research on Striga control in Africa started from the 1940s onwards (Timson, 1945; Andrews, 1947) and, in the last 20 years these efforts have been increased and considerable resources have been invested in developing control options (Oswald, 2005; Woomer, 2004). Several organizations have been involved in conducting research in Kenya and developing Striga control mechanisms: International Maize and Wheat Improvement Centre (CIMMYT) (Odhiambo \& Ransom, 1993); Badische Anilin- und Soda-Fabrik (BASF) a private chemical company; International Centre of Insect Physiology and Ecology (ICIPE) (Khan et al., 2008); International Crops Research Institute for the Semi-Arid-Tropics (ICRISAT) (Haussmann et al., 2001); Tropical Soil Biology and Fertility Program of the International Centre for Tropical Agriculture (TSBF-CIAT) (Vanlauwe et al., 2008); African Agricultural Technology Foundation (AATF) and International Institute of Tropical Agriculture (IITA) (Manyong et al., 2008). Other institutions from advanced countries mostly from Europe (The UK and The Netherlands), USA and Canada have also been involved in conducting research on Striga (Kim, 1996; Andersson \& Halvarsson, 2011). These institutions have recommended control options to farmers in Kenya geared towards reducing infestation and damage. The options include: the use of resistant crop varieties, intercropping of cereals and legumes, crop rotation, use of trap crops that stimulate suicidal germination, and application of manure and nitrogen fertilizer. These options are summarized in Table 3 with factors in favor and against their adoption by farmers in Kenya.

Generally, it has been accepted that Striga control can be possible and sustainable if a wide range of individual technologies are combined into a program of integrated Striga control (ISC) to serve a range of bio-physical and socio-economic environments (Ellis-Jones et al., 2004; Douthwaite et al., 2007). In fact, Franke et al. (2006) reported that ISC approach reduced Striga seed bank by $46 \%$ and improved crop productivity by $88 \%$. The major objective of ISC is to reduce Striga densities in the soil to avoid new plants emerging in the subsequent seasons. However, there is stand-off on the complexity of control options to be involved and farm management as well as the resources required for its implementation.

\section{Conclusion}

Striga infestation in Kenya has increased in size and severity despite the 70 years of support in research. Increased pressure on land, as a result of cereal production (particularly mono cropping) and reduction in the use of fallow, is responsible for the worsening situation. The control methods developed have not been adopted by farmers. The reasons for non-adoption are that the farmers doubt them (Khan et al., 2009; Atera, 2010) and they hear rumours that the methods do not work, and thus they are unwilling to test them. We strongly recommend that researchers and farmers should have an active linkage to technology transfer, as currently transfer of technology seems to be the limiting constraint. In our view, the technique of female sterility should be explored in Striga control in conjunction with intercropping with crop traps that stimulate suicidal germination. The technique will be based on gene introduction into S. hermonthica genome to cause female sterility while maintaining male fertility. On the other hand, intercropping as a farming system will readily be acceptable to farmers and able to fit into their farming requirements. The combination of these control options would increase yields and eliminate the need for alternative methods of eradicating the witchweed. 
Table 3. Factors in favor and against Striga controls options recommended to Kenyan farmers

\begin{tabular}{|c|c|c|c|}
\hline Strategy & Factors in favor of control options & Setbacks for control options & Ref. \\
\hline $\begin{array}{l}\text { Manual } \\
\text { weeding }\end{array}$ & $\begin{array}{l}\text { Reduction of Striga seed bank, easy to } \\
\text { implement }\end{array}$ & $\begin{array}{l}\text { Yield benefit is not immediate, } \\
\text { labor intensive }\end{array}$ & 11,12 \\
\hline Crop rotation & $\begin{array}{l}\text { Increase soil fertility, reduction of Striga } \\
\text { seed bank }\end{array}$ & $\begin{array}{l}\text { Benefit accruement requires time, } \\
\text { costly as per family food } \\
\text { requirement }\end{array}$ & $7,8,14$ \\
\hline Hand pulling & $\begin{array}{l}\text { Reduction of Striga seed bank if done before } \\
\text { flowering, increase in yield }\end{array}$ & $\begin{array}{l}\text { Inappropriate disposal increase } \\
\text { seed bank }\end{array}$ & $10,11,14$ \\
\hline $\begin{array}{l}\text { Allelopathic } \\
\text { effect }\end{array}$ & $\begin{array}{l}\text { Reduction of Striga incidence, increase } \\
\text { yield, provide livestock fed }\end{array}$ & $\begin{array}{l}\text { Crop uneconomical to farmers } \\
\text { without livestock }\end{array}$ & $6,7,14$ \\
\hline \multirow[t]{2}{*}{ Push and pull } & \multirow{2}{*}{$\begin{array}{l}\text { Provide livestock feed, reduction of Striga } \\
\text { seed bank, control of stem borer, } \\
\text { improvement of soil fertility }\end{array}$} & $\begin{array}{l}\text { Costly to implement initially, } \\
\text { benefit accruement requires time, } \\
\text { trap crop }\end{array}$ & \multirow[t]{2}{*}{6,7} \\
\hline & & used uneconomical & \\
\hline $\begin{array}{l}\text { Fertilizer } \\
\text { application }\end{array}$ & $\begin{array}{l}\text { Increase in yield, improvement of soil } \\
\text { fertility, reduction of Striga incidence }\end{array}$ & $\begin{array}{l}\text { Costly to implement, labor } \\
\text { intensive }\end{array}$ & 12,13 \\
\hline Intercropping & $\begin{array}{l}\text { Reduction of Striga seed bank, increase soil } \\
\text { fertility, provide additional income }\end{array}$ & $\begin{array}{l}\text { Labor intensive, trap crop used } \\
\text { uneconomical }\end{array}$ & $3,5,6$ \\
\hline $\begin{array}{l}\text { Seed dressing } \\
\text { (herbicide) }\end{array}$ & $\begin{array}{l}\text { Increase in yield, easy to implement, } \\
\text { Reduction of Striga incidence }\end{array}$ & $\begin{array}{l}\text { Purchase of seed every season is } \\
\text { costly }\end{array}$ & $1,4,10$ \\
\hline $\begin{array}{l}\text { Compost } \\
\text { application }\end{array}$ & $\begin{array}{l}\text { Increase in yield, easy to implement, } \\
\text { reduction of Striga incidence, increase } \\
\text { soil fertility }\end{array}$ & Increase pests, labor intensive & 10,13 \\
\hline $\begin{array}{l}\text { Resistant } \\
\text { crops }\end{array}$ & Easy to implement, high crop yield & $\begin{array}{l}\text { Purchase of seed every season is } \\
\text { costly }\end{array}$ & $7,10,14$ \\
\hline Herbicide & Reduction of Striga seed bank & $\begin{array}{l}\text { Unavailable to farmers, cost } \\
\text { prohibitive }\end{array}$ & 10,11 \\
\hline Transplanting & $\begin{array}{l}\text { Reduction of Striga emergence, } \\
\text { improvement of crop yield }\end{array}$ & Labor intensive & 9 \\
\hline
\end{tabular}

1-De Groote et al., 2008; 2-Gacheru \& Rao 2001; 3-Kanampiu et al., 2002; 4-Kanampiu et al., 2003; 5-Khan et al., 2007; 6-Khan et al., 2008; 7-Manyong et al., 2008; 8-Oswald \& Ransom, 2001; 9-Oswald et al., 2001;10-Oswald, 2005; 11-Ransom, 2000; 12-Ransom \& Odhiambo, 1994; 13-Smaling et al., 1991; 14-Authors'own observations.

\section{Acknowledgement}

The authors are grateful to Mitsui Corporation (08-C-083), Japan, for financial support and Florence Nyaboke Onyancha of KOSFIP, Hombay, Kenya for editing this manuscript.

\section{References}

Abunyewa, A. A., \& Padi, F. K. (2003). Changes in soil fertility and Striga hermonthica prevalence associated with legume and cereal cultivation in the Sudan savannah zone of Ghana. Land Degradation Development, 14, 335-343. http://dx.doi.org/10.1002/ldr.555

Aigbokhan, E. I., Berner, D. K., Musselman, L. J., \& Mignouna, H. D. (2000). Evaluation of variability in Striga aspera, Striga hermonthica and their hybrids using morphological characters and random amplified polymorphic DNA markers. Weed Research, 40, 375-386. http://dx.doi.org/10.1046/j.1365-3180.2000.00198.x

Amudavi, D., Khan, Z., \& Pickett, J. (2007). Enhancing the Push-Pull strategy. LEISA Magazine, 23, 4. 
Andersson, J., \& Halvarsson, M. (2011). The economic consequences of Striga hermonthica in maize production in Western Kenya. Swedish University of Agricultural Sciences, Agricultural Programme-Economics and Management Degree thesis No. 669, Uppsala, pp. 11-23.

Andrews, F. W. (1947). The parasitism of Striga hermonthica Benth. On leguminous plants. Annals Applied Botany, 34, 267-275. http://dx.doi.org/10.1111/j.1744-7348.1947.tb06362.x

Atera, E. A., Itoh, K., Azuma, T., \& Ishii, T. (2012a). Response of NERICA rice to Striga hermonthica infections in western Kenya. International Journal of Agriculture and Biology, 14, 271-275.

Atera, E. A., Itoh, K., Azuma, T., \& Ishii, T. (2012b). Farmers' perspectives on the biotic constraint of Striga hermonthica and its control in western Kenya. Weed Biology and Management, 12, 53-62. http://dx.doi:10.1111/j.1445-6664.2012.00435.x

Atera, E. A. (2010). Effect of Striga infection on NERICA rice cultivars and farmers' perception on its control mechanisms in sub-Saharan Africa. M.Sc. Thesis, Kobe University, Japan, September 2010.

Bharathalakshmi Werth, C. R., \& Musselman, L. J. (1990). A study of genetic diversity among host-specific populations of the witchweed Striga hermonthica (Scrophulariaceae) in Africa. Plant Systematics and Evolution, 172, 1-12.

Bruce, T. J. A. (2010). Tackling the threat to food security caused by crop pests in the new millennium. Food Security, 2, 133-141. http://dx.doi.org/10.1007/s12571-010-0061-8

De Groote, H., Wangare, 1., Kanampiu, F., Odendo, M., Diallo, A., Karaya, H., \& Friesen, D. (2008). The potential of herbicide resistant maize technology for Striga control in Africa. Agricultural Systems, 97, 83-94. http://dx.doi.org/10.1016/j.agsy.2007.12.003.

Doggett, H. (1965). Striga hermonthica on sorghum in East Africa. Journal of Agricultural Science, 65, 183-194. http://dx.doi.org/10.1017/S0021859600083908

Douthwaite, B., Schulz, S., Olanrewaju, A. S., \& Ellis-Jones, J. (2007). Impact pathway evaluation of an integrated Striga hermonthica control project in northern Nigeria. Agricultural Systems, 92, 201-222. http://dx.doi:10.1016/j.agsy.2006.03.007

Dugje, I. Y., Kamara, A. Y., \& Omoigui, L. O. (2006). Infestation of crop fields by Striga species in the savanna zones of northeast Nigeria. Agriculture Ecosystem Environment, 116, 251-254. http://dx.doi.org/10.1016/j.agee.2006.02.013

Ejeta, G. (2007). The Striga scourge in Africa: a growing pandemic. In Ejeta, G., \& Gressel, J. (Eds). Integrating New Technologies for Striga Control. World Scientific Conference, Singapore, pp. 3-16.

Ellis-Jones, J., Schulz, S., Douthwaite, B., Hussaini, M. A., Oyewole, B. D., Olanrewaju, A. S., \& White, R. (2004). An assessment of integrated Striga hermonthica control and early adoption by farmers in northern Nigeria. Experimental Agriculture, 40, 353-368. http://dx.doi.org/10.1017/S0014479704001802

FAO. (2006). World agriculture: towards 2030/2050. Prospects for food, nutrition, agriculture and major commodity groups, Food and Agriculture Organization of the United Nations, Global Perspective Studies Unit, Rome.

Franke, A. C., Ellis-Jones, J., Tarawalia, G., Schulz, S., Hussaini, M. A., Kureh, I., \& Olanrewaju, A. S. (2006). Evaluating and scaling-up integrated Striga hermonthica control technologies among farmers in northern Nigeria. Crop Protection, 25, 868-878. http://dx.doi.org/10.1016/j.cropro.2005.11.014

Gacheru, E., \& Rao, M. R. (2001). Managing Striga infestation on maize using organic and inorganic nutrient sources in western Kenya. International Journal Pest Management, 47, 233-239. http://dx.doi.org/10.1080/09670870110044616

Gethi, J. G., Smith, S. E., Mitchell, S. E., \& Kresovich, S. (2005). Genetic diversity of Striga hermonthica and Striga asiatica population in Kenya Weed Research, 45, 64-73. http://dx.doi.org/10.1111/j.1365-3180.2004.00432.x

Gitau, R., Kimenju, S., Kibaara, B., Nyoro, J., Bruntrup, M., \& Zimmermann, R. (2009). Agricultural policy-making in sub-Saharan Africa: Kenya's past policies. Tegemeo Institute of Agricultural Policy and Development, 1-13.

GoK. (2010). Agricultural sector development strategy 2010-2020. Government of Kenya, 1-17.

Haussmann, B. I. G., Hess, D. E., Reddy, B. V. S., Mukuru, S. Z., Kayentao, M., Welz, H. G., \& Geiger, H. H. 
(2001). Quantitative-genetic parameters of sorghum growth under Striga infestation in Mali and Kenya. Plant Breeding, 120, 49-56. http://dx.doi.org/10.1046/j.1439-0523.2001.00546.x

Hearne, S. J. (2009). Control - the Striga conundrum. Pest Management Science, 65, $603-614$. http://dx.doi.org/10.1002/ps.1735

Kanampiu, F., Ransom, J., Friesen, D., \& Gressel, J. (2002). Imazapyr and pyrithobac movement in soil and from maize seed coats to control Striga in legume intercropping. Crop Protection, 21, 611-619. http://dx.doi.org/10.1016/S0261-2194(01)00151-X

Kanampiu, F. K., Kabambe, V., Massawe, C., Jasi, L., Friesen, D., \& Ransom, J. K. (2003). Multi-site, multi-season field tests demonstrate that herbicide seed-coating herbicide-resistance maize controls Striga spp. and increases yields in several African countries. Crop Protection, 22, 697-706. http://dx.doi.org/10.1016/S0261-2194(03)00007-3

Khan, Z. R., Midega, C. A. O., Amudavi, D. M., Hassanali, A., \& Pickett, J. A. (2008). On farm evaluation of the 'push-pull' technology for the control of stemborers and Striga weed on maize in western Kenya. Field Crop Research, 106, 224-233. http://dx.doi.org/10.1016/j.fcr.2007.12.002

Khan, Z. R., Midega, C. A. O., Hassanali, A., Pickett, J. A., \& Wadhams, L. J. (2007). Assessment of different legumes for the control of Striga hermonthica in maize and sorghum. Crop Science, 47, 730-736. http://dx.doi.org/10.2135/cropsci2006.07.0487

Khan, Z. R., Midega, C. A. O., Wanyama, J. M., Amudavi, D. M., Hassanali, A., Pittchar, J., \& Pickett, J. A. (2009). Integration of edible beans (Phaseolus vulgaris L.) into the push-pull technology developed for stemborer and Striga control in maize-based cropping systems Crop Protection, 28, 997-1006. http://dx.doi:10.1016/j.cropro.2009.05.014

Khan, Z. R., Pickett, J. A., Wadhams, L. J., Hassanali, A., \& Midega, C. A. O. (2006). Combined control of Striga hermonthica and stemborers by maize-Desmodium spp. intercrops. Crop Protection, 25, 989-995. http://dx.doi.org/10.1016/j.cropro.2006.01.008

Kim, S. (1996). Horizontal resistance: core to research breakthrough to combat Striga in Africa. Integrated Pest Management, 1, 229-249. http://dx.doi.org/10.1007/BF00139766

Kim, S., Adetimirin, V. O., \& Akintunde, A. Y. (1997). Nitrogen effects on Striga hermonthica infestation, grain yield, and agronomic traits of tolerant and susceptible maize hybrids. Crop Science, 37, 711-716.

Koyama, M. L. (2000). Genetic variability of Striga hermonthica and effect of resistant cultivars on Striga population dynamics. In B. I. G. Hausmann, D. E. Hess, M. L. Koyama, L. H. F. W. Grivet Rattunde \& H. H. Geiger (Eds.), (pp. 247-260). Breeding for Striga resistance in cereals. Proceedings of a workshop held at IITA, Ibadan, Nigeria. Margraf Verlag, Weikersheim, Germany.

MacOpiyo, L., Vitale, J., \& Sanders, J. (2010). An ex-ante assessment of a Striga control programme in East Africa. Kilimo Trust, pp. 6-25.

Manyong, V. M., Nindi, S. J., Alene, A. D., Odhiambo, G. D., Omanya, G., Mignouna, H. D., \& Bokanga, M. (2008). Farmer Perceptions of Imazapyr- Resistant (IR) Maize Technology on the Control of Striga in Western Kenya. African Agricultural Technology Foundation, Nairobi, Kenya, pp. 27- 31.

Ministry of Agriculture. (2010). Economic review of agriculture, Nairobi, Kenya, pp. 25-32.

Mohamed, K. I., Bolin, J. F., Musselman, L. J., \& Peterson, A. T. (2007). Genetic diversity of Striga and implications for control and modeling future distributions. In G. Ejeta \& J. Gressel (Eds.), Integrating new technologies for Striga control: towards ending the witch-hunt. (pp. 71-84). World Scientific Conference, Singapore.

Mohamed, K. I., Musselman, L. J., \& Riches, C. R. (2001). The genus Striga (scrophulariaceae) in Africa. Annals of Missouri Botany garden, 88, 60-103.

Murray, B. G., Hammet, K. R.W., \& Herrick, J. F. (1993). Relationship between Lathyrus cassus, L. odoratus, and L. hirsutus assessed by experimental hybridization, analysis of meiotic pairing and DNA: DNA hybridization. International Journal of Plant Science, 154, 163-168. http://dx.doi.org/10.1086/297101

Odhiambo, G. D., \& Ransom, J. K. (1993). Effect of Dicamba on the control of Striga hermonthica in maize in western Kenya. African Crop Science Journal, 1, 105-110.

Olivier, A., Glaszmann, J. C., Lanaud, C., \& Leroux, G. D. (1998). Population structure, genetic diversity and 
host specificity of the parasitic weed Striga hermonthica (Scrophulariaceae) in Sahel. Plant Systematics and Evolution, 209, 33-45.

Oswald, A. (2005). Striga control-technologies and their dissemination. Crop Protection, 24, 333-342. $\mathrm{http}: / / \mathrm{dx}$.doi.org/10.1016/j.cropro.2004.09.003

Oswald, A., \& Ransom, J. K. (2001). Striga control and improved farm productivity using crop rotation. Crop Protection, 20, 113-120. http://dx.doi.org/10.1016/S0261-2194(00)00063-6

Oswald, A., Ransom, J. K., Kroschel, J., \& Sauerborn, J. (2001). Transplanting maize and sorghum reduces $\begin{array}{llll}\text { Striga hermonthica } & \text { Wamage. }\end{array}$ http://dx.doi.org/10.1614/0043-1745(2001)049[0346:TMASRS]2.0

Parker, C. (2009). Observations on the current status of Orobanche and Striga problems worldwide. Pest Management Science, 65, 453-459. http://dx.doi.org/10.1002/ps.1713

Ransom, J. K. (2000). Long-term approaches for the control of Striga in cereals: field management option Crop Protection, 19, 759-763. http://dx.doi.org/10.1016/S0261-2194(00)00101-0

Ransom, J. K., \& Odhiambo, G. D. (1994). Long-term effects of fertility and hand weeding on Striga in maize. In A. H. Pieterse, J. A. C. Verkleij, \& J. S. Borg (Eds.), Biology and Management of Orobanche. Proceedings of the third international conference on Orobanche and related Striga research (pp. 513-519). Royal Tropical Institute, Amsterdam.

Smaling, E. M. A., Stein, A., \& Sloot, P. H. M. (1991). A statistical analysis of the influence of Striga hermonthica on Maize yields in fertilizer trials in Southwestern Kenya. Plant and soil, 138, 1-8. http://dx.doi.org/10.1007/BF00011801

Taylor, J. R. N. (2009). Developments in Africa's cereal crops - potential resources for breeding in tropical and sub-tropical countries. Institute of brewing \& distilling sect. - $12^{\text {th }}$ Scientific and Technical convention. University of Pretoria, South Africa.

Timson, S. D. (1945). Witchweed demonstration farm: final progress report. December 1944. Rhodesia Agriculture Journal, 42, 404-409.

United Nations Population Division. (2007). World Population Prospects: The 2006 revision population database. Retrieved from http://esa.un.org/unpp

van Delft, G. J., Graves, J. D., Fitter, A. H., \& Pruiksma, M. A. (1997). Spatial distribution and population dynamics of Striga hermonthica seeds in naturally infested farm soils. Plant and Soil, 195, 1-15. http://dx.doi.org/10.1023/A:1004214015281

Vanlauwe, B., Kanampiu, F., Odhiambo, G. D., De Groote, H., Wadhams, H. J., \& Khan, Z. R. (2008). Integrated management of Striga hermonthica, stemborers, and declining soil fertility in Western Kenya. Field Crops Research, 107, 102-115. http://dx.doi:10.1016/j.fcr.2008.01.002

Watt, W. L. (1936). Control of Striga weed in Nyanza Province, Kenya. East African Agriculture Journal, 320-322.

Weber G., Elemo, K., Lagoke, S. T. O., Awad, A., \& Oikeh, S. (1995). Population dynamics and determinants of Striga hermonthica on maize and sorghum in savanna farming systems. Crop Protection, 14, 283-290. http://dx.doi.org/10.1016/0261-2194(94)00004-R

Welsh, A. B., \& Mohamed, K. I. (2011). Genetic diversity of Striga hermonthica populations in Ethiopia: Evaluating the role of geography and host specificity in shaping population structure. International Journal Plant Sciences, 172, 773-782. http://www.jstor.org/doi: 10.1086/ 660104

Westerman, P. R., van Ast, A., Stomph, T. J., \& van Der Werf, W. (2007). Long-term management of the parasitic weed Striga hermonthica: Strategy evaluation with a population model. Crop Protection, 26, 219-227. http://dx.doi.org/10.1016/j.cropro.2006.01.017

Woomer, P. (2004). New approaches to controlling Striga infestation: AATF Striga Management project. Farmers Journal, 1-3.

Woomer, P. L., \& Savala, C. E. N. (2009). Mobilizing Striga control technologies in Kenya. African Crop Science Conference Proceedings, 9, 677-681.

Wright, S. (1978). Evolution and the genetics of populations: Variability within and among natural populations. University of Chicago Press, Chicago. 